\title{
Penyuluhan Pembuatan dan Pemanfaatan Pupuk Organik Cair di Kelompok Tani Sougp Hatam 1 Kampung Lismaunggu Distrik Prafi, Kabupaten Manokwari Provinsi Papua Barat
}

\author{
Yaer Karenius Mandacan ${ }^{1}$, Detia Tri Yunandar ${ }^{1}$, Susanti Indriya Wati ${ }^{1 *}$ \\ ${ }^{1}$ Program Studi Penyuluhan Pertanian Berkelanjutan, Politeknik Pembangunan Pertanian \\ Manokwari \\ *Corresponding author: susankopiholic@gmail.com
}

\begin{abstract}
Abstrak
Negara Indonesia dikenal sebagai Negara agraris, dimana sebagian besar penduduk Indonesia bermata pencaharian sebagai petani. Namun pada saat ini para petani dihadapkan dengan permasalahan harga pupuk anorganik yang harganya melambung tinggi, sehingga para petani mengalami kerugian dikarenakan biaya produksi yang terlalu tinggi oleh karena itu diperlukan adanya teknologi yang mampu mendukung permasalahan pupuk di Indonesia salah satunya penggunaan pupuk organik cair (POC) berbahan organik batang pisang. Penelitian ini bertujuan untuk menganalisis dampak penyuluhan pada pengetahuan petani tentang pembuatan dan manfaat pupuk organik cair dan menganalisis dampak penyuluhan pada sikap petani terhadap pembuatan dan pemanfaatan pupuk organik cair. Penelitian ini dilaksanakan pada bulan April - Juni 2020 bertempat di Kampung Lismaunggu, Distrik Prafi, Kabupaten Manokwari, Provinsi Papua Barat. Hasil penelitian menunjukkan kesesuaian antara pelaksanaan dengan pedoman cara pembuatan Pupuk Organik Cair (POC) dari Batang Pisang serta peningkatan pengetahuan petani dikelompok tani Sougp Hatam 1 Kampung Lismaunggu, Distrik Prafi, Kabupaten Manokwari, Provinsi Papua Barat.
\end{abstract}

Kata kunci: Pupuk organik cair, POC, Batang pisang

\begin{abstract}
The Indonesian state is known as an agricultural country, where most of the Indonesian population works as farmers. However, at this time farmers are faced with the problem of inorganic fertilizer prices, which prices are soaring, so that farmers experience losses due to high production costs, therefore it is necessary to have technology that can support fertilizer problems in Indonesia, one of which is the use of liquid organic fertilizer (POC) made from organic banana stems. This study aims to analyze the impact of extension on farmers 'knowledge about the manufacture and benefits of liquid organic fertilizers and to analyze the impact of extension on farmers' attitudes towards the manufacture and use of liquid organic fertilizers. This research was conducted in April - June 2020 at Lismaunggu Village, Prafi District, Manokwari Regency, West Papua Province. The results showed the suitability between the implementation with the guidelines for how to make Liquid Organic Fertilizer (POC) from Batang Pisang and increasing the knowledge of farmers in the Sougp Hatam 1 farmer group, Lismaunggu Village, Prafi District, Manokwari Regency, West Papua Province.
\end{abstract}

Key words: Liquid organic fertilizer, POC, Banana stem 
Prosiding Seminar Nasional Pembangunan dan Pendidikan Vokasi Pertanian

Politeknik Pembangunan Pertanian Manokwari, 14 November 2020

e ISSN : 2774-1982

\section{PENDAHULUAN}

Pendahuluan berisi urgensi dan latar belakang masalah penelitian yang diuraikan dengan metode piramida terbalik mulai dari tingkat global, nasional dan lokal. Mencantumkan referensi (pustaka atau hasil penelitian relevan), sebagai contoh: Pengertian penyuluhan dalam arti umum adalah ilmu sosial yang mempelajari sistem dan proses perubahan pada individu serta masyarakat agar terwujud perubahan yang lebih baik sesuai dengan yang diharapakan (Setiana, 2005).

Pendahuluan berisi tinjauan latar belakang secara umum dan tinjauan literatur (state of the art), usahakan minimum 5 literatur yang dikupas yang dapat menjustifikasi kebaruan atau novelty atau keunikan penelitian ini dibandingkan penelitian sebelumnya (biasanya 2-3 paragraf). Jumlah halaman pada bagian pendahuluan sebanyak 1-2 halaman yang ditulis dengan menggunakan Times New Roman 11 point (tegak) dengan spasi 1,5. Tiap paragraf diawali dengan Indentasi $1 \mathrm{~cm}$. Bagian akhir pendahuluan harus mengemukakan tujuan penelitian.

Negara Indonesia dikenal sebagai Negara agraris, dimana sebagian besar penduduk Indonesia bermata pencaharian sebagai petani. Namun pada saat ini para petani dihadapkan dengan permasalahan harga pupuk anorganik yang harganya melambung tinggi, sehingga para petani mengalami kerugian dikarenakan biaya produksi yang terlalu tinggi. Akhirakhir ini berkembang wacana untuk kembali ke alam (back to nature) dalam kegiatan pertanian, diantaranya dengan pemanfaatan bahan-bahan alam (sumber daya hayati) untuk kebutuhan pupuk dan pestisida (pengendali hama) yang dikenal dengan system pertanian organik yang ramah lingkungan. Sebagian besar petani masih menggunakan cara budidaya yang sangat sederhana dan hanya dilakukan sesuai dengan pengetahuan mereka saja terutama pada penggunaan pupuk anorganik. Pemberian pupuk anorganik seperti Urea, SP36 dan NPK yang mengandung berbagai senyawa kimia dapat memberikan dampak negatif pada tanah jika digunakan dalam jangka waktu yang relatif lama. Tanah menjadi cepat mengeras dan kemampuan menyimpan air berkurang, sehingga produktivitas tanaman akan menurun dikarenakan tanah menjadi asam (Parman, 2007). Pupuk organik secara ekonomis jauh lebih terjangkau dibandingkan pupuk anorganik, sehingga dapat mengurangi biaya produksi pertanian (Lingga, 2007). Bertitik tolak dari hal tersebut, salah satu upaya yang dapat dilakukan dalam bidang pertanian adalah mengembangkan pertanian dengan sistem pertanian organik yang prinsip pengelolaannya kembali ke alam.

Menurut Sutanto (2002), penggunaan pupuk organik cair (POC) merupakan salah satu cara untuk mengatasi kekurangan bahan organik, karena mampu memperbaiki sifat 
Prosiding Seminar Nasional Pembangunan dan Pendidikan Vokasi Pertanian

Politeknik Pembangunan Pertanian Manokwari, 14 November 2020

e ISSN : 2774-1982

fisik, kimia, dan biologi tanah. Selain itu dapat meningkatkan hasil baik kualitas maupun kuantitas serta mampu mengurangi penggunaan pupuk anorganik. POC merupakan pupuk organik yang berbentukcairan atau larutan yang mengandung unsur hara tertentu yang bermanfaat bagi pertumbuhan tanaman. Bahan baku pupuk cair dapat berasal dari berbagai macam bahan organik yang disesuaikan dengan kondisi setempat. Penggunaan pupuk cair dapat disiramkan atau disemprotkan pada bagian tanaman. Secara kualitatif, kandungan unsur hara yang ada dalam pupuk organik tidak dapat lebih tinggi dari pada pupuk anorganik atau pupuk kimia. Namun beberapa penelitian menunjukan bahwa pemberian POC pada tanaman mampu meningkatkan produksi tanaman melalui aktivasi mikroorganisme yang terkandung didalamnya maupun yang ada di lingkungan. Salah satu bahan yang dapat digunakan untuk pembuatan POC adalah batang pisang. Batang pisang atau disebut Wupato (bahasa Gorontalo) mengandung unsur yang dibutuhkan oleh tanaman, sehingga limbah yang satu ini patut mendapat perhatian untuk dimanfaatkan sebagai bahan pupuk cair. Menurut Suprihatin (2011) batang pisang mempunyai kandungan kimia seperti kalsium 16\%, kalium 23\% dan fospor 32\%. Ketersediaan batang pisang sangat melimpah karena petani pada umumnya hanya membiarkan batang pisang tersebut hingga membusuk begitu saja,setelah memanen buahnya.

Pisang merupakan tanaman yang tidak asing lagi di kalangan masyarakat. Pisang (Musa paradisiaca) berasal dari Asia dan tersebar di Spanyol, Itali, Indonesia serta Amerika. Pisang merupakan salah satu buah tropik yang mempunyai nilai ekonomi tinggi, ketersediaannya tidak mengenal musim dan harganya terjangkau. Tanaman pisang bersifat monokarfik artinya hanya berbuah sekali dan kemudian mati. Tanaman pisang akan berproduksi dengan baik apabila pertumbuhannya juga subur. Pisang umumnya dapat tumbuh di dataran rendah dengan ketinggian $1.000 \mathrm{~m}$ diatas permukaan laut. Pisang dapat tumbuh pada iklim tropis basah, lembab dan panas. Meskipun demikian pisang dapat tumbuh di dataran tinggi sampai ketinggian $1.300 \mathrm{~m}$ diatas permukaan laut. Di dataran tinggi umur tanaman sampai berbuah lebih lama dan kulitnya lebih tebal. Seiring meningkatnya pengetahuan dibidang pertanian, batang pohon pisang kini mulai dimanfaatkan sebagai pupuk organik cair. Pupuk merupakan bahan yang ditambahkan ke dalam tanah untuk menyediakan unsur-unsur esensial bagi pertumbuhan tanaman. Jika dilihat berdasarkan sumber bahan yang digunakan, pupuk dibedakan menjadi pupuk anorganik dan pupuk organik. Berdasarkan bentuknya, pupuk organik dibagi menjadi dua, yaitu pupuk cair dan pupuk padat. Pupuk cair adalah larutan yang mudah larut berisi satu 
Prosiding Seminar Nasional Pembangunan dan Pendidikan Vokasi Pertanian

Politeknik Pembangunan Pertanian Manokwari, 14 November 2020

e ISSN : 2774-1982

atau lebih pembawa unsur yang dibutuhkan tanaman. Kelebihan dari pupuk cair yaitu dapat memberikan hara sesuai dengan kebutuhan tanaman (Hadisuwito, 2012).

Pupuk organik merupakan. Menyiram tanaman,Mengobati tanaman.Pupuk cair tersebut dapat dibuat dari kotoran hewan dan dari limbah tanaman seperti batang pisang. Dalam pertumbuhannya tanaman memerlukan tiga unsur hara penting, yaitu calcium $(\mathrm{Ca})$ , fosfat (P), dan kalium (K). Batang pohon pisang memiliki kandungan selulosa yang cukup tinggi. Kandungan yang terdapat pada batang pisang sebagian besar berisi asir dan serat (selulosa), disamping bahan mineral kalium, kalsium, fosfor, besi (Satuhu \& Supriadi, 1999). Saraiva et al. (2012) mengemukakan bahwa ekstrak batang pisang memiliki kandungan unsur $\mathrm{P}$ berkisar antara $0,2-0,5 \%$ yang bermanfaat menambah nutrisi untuk pertumbuhan dan produksi tanaman. Oleh karna itu batang pisang dapat dimanfaatkan sebagai pupuk organik cair. Pupuk adalah bahan yang ditambahkan ke dalam tanah untuk menyediakan essensial bagi pertumbuhan tanaman.

SLPHT dikatakan berhasil apabila tujuan dari program SLPHT dapat tercapai. Untuk mengetahui keberhasilan program tersebut maka perlu dilakukan evaluasi, Evaluasi ini bertujuan untuk mengetahui seberapa jauh tingkat pengetahuan tani lokal terhadap inovasi POC dari batang pisang. Dalam penelitian kali ini peneliti akan mengevaluasi tingkat pengetahuan tani lokal di kelompok tani Sougp Hatam 1 cara pembuatan dan pemanfaatan Pupuk Organik Cair (POC) dari Batang Pisang Kampung Lismaunggu, Distrik Prafi, Kabupaten Manokwari, Provinsi Papua Barat.. Penelitian dilakukan ditempat ini oleh peneliti dikarenakan menurut hasil pemantaun yang dilakukan peneiti, Kelompok Tani Sougp Hatam 1 di kampung lismaunggu menggunakan POC.

\section{METODE}

Bagian ini menjelaskan tentang jenis penelitian diantaranya jenis penelitian kuantitatif atau kualitatif, Penelitian kualitatif seperti studi kasus, fenomenologi, etnografi, dan lain-lain, perlu menambahkan uraian mengenai pengecekan keabsahan hasil penelitian. Penelitian kuantitatif menjelaskan lokasi dan waktu penelitian, populasi dan sampel, teknik sampling, teknik pengumpulan data, analisis data, dan penyajian data. Penelitian yang menggunakan alat dan bahan, perlu menuliskan spesifikasi alat dan bahan yang digunakan. Penulisan menggunakan Times New Roman 11 point (tegak) dengan spasi 1,5. Tiap paragraf diawali dengan Indentasi $1 \mathrm{~cm}$ dan tidak boleh menggunakan pengorganisasian penulisan ke dalam "anak sub-judul” pada bagian ini. Ditampilkan dalam 1-2 paragraf. 
Prosiding Seminar Nasional Pembangunan dan Pendidikan Vokasi Pertanian

Politeknik Pembangunan Pertanian Manokwari, 14 November 2020

e ISSN : 2774-1982

\section{Lokasi dan Waktu}

Kegiatan penelitian ini dilaksanakan didaerah lokal khususnya pada kelompok tani Sougp Hatam 1 cara pembuatan dan pemanfaatan Pupuk Organik Cair (POC) dari Batang Pisang Kampung Lismaunggu, Distrik Prafi, Kabupaten Manokwari, Provinsi Papua Barat. Kegiatan penelitian ini telah dilaksanakan selama kurang lebih 3 bulan yaitu terhitung mulai dari bulan April-Juni 2020.

\section{Metode Penelitian}

Menurut Arikunto (2007) jenis data yang dikumpulkan terdiri dari data primer dan data sekunder yang sifatnya kualitatif maupun kuantitatif yang diperoleh dari lapangan/obyek penelitian.

\section{a) Data Primer}

Data primer adalah data yang dikumpulkan oleh peneliti sendiri atau dirinya sendiri. Ini adalah data yang belum pernah dikumpulkan sebelumnya, baik dengan cara tertentu atau pada periode waktu tertentu, data ini diambil dari hasil wawancara, observasi, kuisioner dan dokumentasi yang di dapatkan di lapangan.

\section{b) Data Sekunder}

Data sekunder adalah data yang dikumpulkan oleh orang lain, bukan peneliti itu sendiri. Data ini biasanya berasal dari penelitian lain yang dilakukan oleh lembagalembaga atau organisasi.

\section{Teknik Pengumpulan Data}

Teknik Pengumpulan data adalah sebagai berikut:

a. Kuisioner, adalah teknik pengumpulan data yang dilakukan dengan cara memberikan seperangkat pertanyaan atau pernyataan kepada orang lain yang dijadikan responden untuk dijawabnya.

b. Wawancara, yaitu pengumpulan data dengan melakukan wawancara mendalam langsung kepada informan terpilih dengan menggunakan alat pemandu

c. Observasi, yaitu pengumpulan data dengan mengamati langsung dan memahami kondisi obyektif lokasi penelitian.

d. Dokumentasi, digunakan untuk menggumpulkan data sekuder melalui dokumendokumen, laporan-laporan, dan lain-lain. 
Prosiding Seminar Nasional Pembangunan dan Pendidikan Vokasi Pertanian

Politeknik Pembangunan Pertanian Manokwari, 14 November 2020

e ISSN : 2774-1982

\section{Syarat sampel}

Adapun syarat sampling yang di anjurkan untuk penelitian yaitu:

a. Petani yang cukup memahami tentang POC.

b. Memiliki pengetahuan, kemampuan dan keahlian petani/kelompok tani dalam menganalisa data dan informasi agroekosistem.

c. Mampu memasyarakatkan dan melembagakan penerapan PHT dalam pengelolaan usahatani dan meningkatkan pengamanan produksi terhadap gangguan organisasi pengganggu tanaman dalam pencapaian sasaran produksi, produktivitas dan peningkatan kesejahteraan petani.

\section{Alat dan Bahan}

Alat yang di gunakan dalam penelitian ini adalah: alat tulis menulis, kamera, laptob, printer dan kuisioner. Adapun bahan yang diperlukan dalam penelitian ini adalah: kertas, dan tinta print.

\section{Tahapan penelitian}

Kegiatan penelitian mengenai pemanfaatan POC dan tingkat pengetahuan petani terhadap POC dilaksanakan dalam beberapa tahap, yaitu: (1) Observasi lapangan, (2) Wawancara dengan sumber informasi yaitu penyuluh, (3), Penyusunan Proposal penelitian (4) pembuatan kuesioner, (5) Seminar proposal penelitian, (6) pengambilan data di lokasi penelitian, (7) penyusunan laporan hasil penelitian, (8) seminar hasil penelitian dan (9) finalisasi laporan hasil penelitian.

\section{Variabel penelitian}

Nazir, (1999) mengatakan bahwa variabel merupakan obyek penelitian atau apa yang menjadi titik perhatian suatu penelitian. Sedangkan Menurut Sugiyono (2013) bahwa yang dimaksud dengan variabel adalah suatu atribut atau sifat atau nilai dari orang, objek atau kegiatan yang mempunyai variasi tertentu yang ditetapkan oleh peneliti untuk dipelajari dan ditarik kesimpulannya. Berdasarkan pengertian diatas maka variabel yang ada dalam penelitian tentang pemanfaatan POC dan tingkat pengetahuan petani terhadap POC yang diukur melalui beberapa indikator, yaitu: penyiapan alat dan bahan pembuatan POC, cara pembuatan POC, dan cara pengaplikasian POC terhadap ubi jalar.

\section{Metode Pengambilan Sample}

a. Populasi

Menurut Sugiyono, (2013) Populasi adalah wilayah generalisasi yang terdiri atas obyek/subyek yang mempunyai kualitas dan karakteristik tertentu yang diterapkan oleh peneliti untuk dipelajari dan kemudian ditarik kesimpulannya.Dari pengertian diatas, 
Prosiding Seminar Nasional Pembangunan dan Pendidikan Vokasi Pertanian

Politeknik Pembangunan Pertanian Manokwari, 14 November 2020

e ISSN : 2774-1982

menunjukan bahwa populasi bukan hanya manusia tetapi bisa juga obyek atau benda-benda subyek yang dipelajari seperti dokumen-dokumen yang dapat dianggap sebagai objek penelitian. Populasi juga bukan sekedar jumlah yang ada pada obyek/subyek yang dipelajari, tetapi meliputi seluruh karakteristik atau sifat yang dimiliki oleh subyek atau obyek itu. Populasi dalam penelitian ini adalah kelompok tani Sougp Hatam 1 dikampung lismaunggu. Berdasarkan data yang di peroleh jumlah populasi anggota kelompok tani Sougp Hatam 1 (satu) 15 orang di Kampung Lismaunggu.

Tabel 1. Jumlah Populasi

\begin{tabular}{ccc}
\hline No & Kelas & Populasi \\
\hline 1. & Anggota kelompok tani Sougp Hatam 1 & 15 \\
\hline
\end{tabular}

Sumber Data: Data Sekunder

b. Sampel

Sugiyono, (2013) menyatakan bahwa sampel adalah bagian dari jumlah dan karakteristik yang dimiliki oleh populasi tersebut. Pengukuran sampel merupakan suatu langkah untuk menentukan besarnya sampel yang diambil dalam melaksanakan suatu penelitian. Dalam pemilihan jenis sampel peneliti menggunakan sampling jenuh. Menurut Sugiyono, (2001) adalah teknik penentuan sampel bila semua anggota populasi digunakan sebagai sampel. Hal ini sering dilakukan bila jumlah populasi relatif kecil, kurang dari 30 orang. Istilah lain sampel jenuh adalah sensus, dimana semua anggota populasi dijadikan sampel.

Tabel 2. Jumlah Sampel

\begin{tabular}{ccccc}
\hline No & Kelas & Populasi & $\begin{array}{c}\text { Persentase } \\
(100 \%)\end{array}$ & Sampel \\
\hline 1. & $\begin{array}{c}\text { kelompok tani Sougp } \\
\text { Hatam 1 }\end{array}$ & 15 & 100 & 15 \\
\hline \multicolumn{2}{c}{ Jumlah } & & & 15 \\
\hline
\end{tabular}

Sumber Data: Data Sekunder

c. Teknik Analis Data

Menurut Arikunto (2007) data yang telah dikumpulkan dianalisis dengan menggunakan teknik yaitu:

Analisis Kualitatif, dimaksudkan untuk mendeskripsikan ciri-ciri atau karakteristik data dalam bentuk naratif. Analisis Kuantitatif, digunakan untuk menganalisis data kualitatif dalam bentuk Distribusi frekuensi, diagram dan tabel. 
Prosiding Seminar Nasional Pembangunan dan Pendidikan Vokasi Pertanian Politeknik Pembangunan Pertanian Manokwari, 14 November 2020

e ISSN : 2774-1982

\section{d. Analisis Data}

Menurut Sugiyono, (2013) Analisis data merupakan kegiatan setelah data dari seluruh responden terkumpul. Kegiatan dalam analisis data adalah mengelompokkan data berdasarkan variabel dan jenis responden, menstabulasi data berdasarkan variabel dari seluruh responden, menyajikan data dari setiap variabel yang diteliti, melakukan perhitungan untuk menjawab rumusan masalah dan melakukan perhitungan untuk menguji hipotesis yang telah diajukan. Berdasarkan pernyataan tersebut maka evaluasi tingkat pengetahuan petani lokal kelompok tani Sougp Hatam 1 terhadap pembuatan POC dan pemanfaatan POC didunia pertanian organik diukur dengan menggunakan kuisioner yang terdiri dari 14 pertanyaan dengan skor 5 jika jawaban Ya dan skor 1 jika jawaban Tidak. Pertanyaan-pertanyaan tersebut terdiri dari pertanyaan tentang indikator kontek, input, proses, dan produk. Sehingga diperoleh nilai maksimum (70) dan nilai minimum (14).

Selanjutnya nilai-nilai tersebut diakumulasikan untuk menentukan tingkat pengetahuan kelompok tani Sougp Hatam 1 terhadap pembuatan POC dan pemanfaatan POC menjadi 5 kategori dengan rumus interval yaitu:

$$
\begin{aligned}
\text { Interval } & =\frac{\text { Nilai Tertinggi }- \text { Nilai Terendah }}{\text { Jumlah Kategori }} \\
& =\frac{70-14}{5}=\frac{56}{5}=11,2=11
\end{aligned}
$$

Berdasarkan nilai interval tersebut maka tingkat dampak program SLPHT terhadap petani peserta SLPHT dikategorikan sebagai berikut:

Tabel 3. Kategori nilai interval

\begin{tabular}{ccc}
\hline No & Skor & Kategori \\
\hline 1. & $59-70$ & Sangat baik \\
2. & $48-58$ & Baik \\
3. & $37-47$ & Cukup baik \\
4. & $26-36$ & Kurang baik \\
5. & $14-25$ & Tidak baik \\
\hline
\end{tabular}

Untuk mengetahui tingkat pencapaian pengetahuan kelompok tani Sougp Hatam 1 terhadap pembuatan POC dan pemanfaatan POC pada ubi jalar diukur menggunakan kuesioner. Hasil kuesioner dibagi dalam dua kategori yaitu kategori positif dan kategori negatif. Jika tanggapan responden mencapai harapan (positif) maka, kelompok tani Sougp Hatam 1 mencapai harapan penelitian terhadap tingkat pengetahuan pembuatan POC dan 
Prosiding Seminar Nasional Pembangunan dan Pendidikan Vokasi Pertanian

Politeknik Pembangunan Pertanian Manokwari, 14 November 2020

e ISSN : 2774-1982

pemanfaatan POC pada ubi jalar berlanjut pada sektor pertanian. Jika tanggapan responden tidak mencapai harapan (negatif) maka, kelompok tani Sougp Hatam 1 tidak mencapai harapan penelitian terhadap tingkat pengetahuan pembuatan POC dan pemanfaatan POC pada ubi jalar berlanjut pada sektor pertanian.

\section{Rancangan Analisis Data}

Metode analisis data yang digunakan adalah analisis domain yaitu analisis dengan mendekati suatu masalah secara langsung Sugiyono, (2013). Secara sistematis metode analisis ini dilakukan melalui tahap-tahap sebagai berikut:

\section{Pengumpulan Data}

Data penelitian didapatkan dengan cara melakukan wawancara, observasi dan pencatatan.

\section{Reduksi Data}

Reduksi data dilakukan dengan pengelolaan data dimulai dari tahap editing, pengkodean dan tabulasi. Reduksi data dilakukan terus-menerus selama proses penelitian berlangsung. Pada tahap ini setelah data dipilah kemudian disederhanakan, data yang tidak perlukan akan disortir agar memberikan kemudahan dalam penampilan, penyajian, serta untuk menarik kesimpulan sementara dari sebuah penelitian.

\section{Penyajian Data}

Sajian data mengacu pada rumusan masalah yang telah dibuat sebagai jawaban pertanyaan-pertanyaan penelitian sehingga narasi yang tersaji merupakan deskripsi mengenai kondisi yang rinci untuk menceritakan dan menjawab setiap permasalahan yang ada.

\section{Penarikan Kesimpulan}

Pada waktu pengumpulan data sudah berakhir, peneliti mulai melakukan usaha untuk menarik kesimpulan berdasarkan semua hal yang terdapat dalam reduksi atau sajian datanya. Kesimpulan-kesimpulan final mungkin tidak muncul sampai pengumpulan data berakhir, tergantung pada besarnya kumpulan-kumpulan catatan lapangan, pengkodeannya, penyimpanannya, metode pencarian ulang yang digunakan.

\section{HASIL DAN PEMBAHASAN}

\section{Keadaan Umum Wilayah}

\section{Deskripsi Umum}

Kampung Lismaunggu secara administratif termasuk dalam wilayah distrik prafi kabupaten manokwari. Sebelumnya warga kampung Lismaunggu merupakan warga 
Prosiding Seminar Nasional Pembangunan dan Pendidikan Vokasi Pertanian

Politeknik Pembangunan Pertanian Manokwari, 14 November 2020

e ISSN : 2774-1982

kampung Nimbay, dan menjadi kampung Lismaunggu atas usulan masyarakat kepada pemerintah daerah kabupaten manokwari. Kampung lismaunggu yang baru ini dihuni oleh masyarakat sejak tahun 1999, secara geografis terletak pada ketinggian $0-4 \mathrm{~m}$ dari permukaan air laut.

Batas wilayah kampung lismaunggu adalah sebagai berikut:

a. Sebelah Utara berbatasan dengan Gunung Lismaunggu

b. Sebelah selatan berbatasan dengan kampung nimbay

c. Sebelah barat berbatasan dengan kali aimasi

d. Sebelah timur berbatasan dengan kampung desay dan prafi mulya

jarak antara kampung lismaunggu dengan ibu kota distrik kurang lebih 3 km, dengan kondisi jalan beraspal sedangkan jarak antara kampung lismaunggu dengan ibu kota kabupaten manokwari kurang lebih $58 \mathrm{~km}$, yang dapat ditempuh dengan perjalanan kurang lebih 1,5 jam.

\section{Karakteristik Lahan}

Kondisi tanah yang ada di kampung lismaunggu umumnya berasal dari endapan (Alluvial) dan liat berpasir dengan kedalaman elektif kurang lebih $73 \mathrm{~cm}$. jenis tanah Alluvial terbagi menjadi 2 yaitu, inceptisol atau tanah berbatu dan entisol atau tanah tidak berbatu.

\section{Karakteristik Iklim}

Kampung lismaunggu dan sekitarnya beriklim type B menurut schidmit dan ferguson dan tergolong type iklim basah. Berdasarkan data iklim dari badan meteorologi dan geofisika rendani tahun 2013/2014, kampung lismaunggu memiliki rata - rata curah hujan per tahun sebesar 210,06 mm dan rata - rata 14,19 hari hujan tiap bulan. Data lengkap mengenal keadaan iklim di kampung lismaunggu dapat dilihat pada lampiran.

\section{Vegetasi}

Kampung lismaunggu memiliki daerah hutan yang terdapat disebelah utara dari lokasi permukiman. Daerah hutan tersebut terdiri dari berbagai vegetasi yang berupa hutan primer dan skunder yang sebagian besar terdiri dari jenis - jenis kayu yaitu : kayu matoa, kayu besi, kayu susu, kayu cina, kayu dao, kayu binuang atau kinem, kayu adai, kayu linggua, kayu moref dan lain - lain.

Kampung lismaunggu juga memiliki tanaman yang bernilai ekonomis yang dibudidayakan antara lain jagung, kacang tanah, ubi jalar, ubi kayu, keladi, tomat, kacang panjang, terong, lombok, pisang, pepaya, serta tanaman non budidaya dan lain - lainnya. Sedangkan jenis ternak yang diusahakan adalah babi dan ayam. 
Prosiding Seminar Nasional Pembangunan dan Pendidikan Vokasi Pertanian

Politeknik Pembangunan Pertanian Manokwari, 14 November 2020

e ISSN : 2774-1982

\section{Hidrologi dan kualitas air}

Dalam memenuhi kebutuhan air sehari - hari, warga kampung lismaunggu menggunakan sumber air yang berasal dari sumur, air hujan dan air sungai (sungai aimasi). Kualitas air sumur penduduk umumnya bersih, jernih, tidak berasa dan tidak berbau, sehingga dapat digunakan untuk memasak, mandi dan mencuci.

\section{Penggunaan Lahan}

Kampung lismaunggu memiliki luas wilayah 150 ha yang penggunaannya adalah sebagai berikut.

Tabel 4. Luas Lahan Menurut Penggunaanya

\begin{tabular}{llcc}
\hline \hline No & Jenis Penggunaan & Luas (Ha) & Persentasi (\%) \\
\hline \hline 1. & Perkebunan kelapa sawit & 125 & 75 \\
2. & Perkarangan & 15 & 10 \\
3. & Fasilitas umum & 2 & 3 \\
4. & Hutan/lahan/sungai & 3 & 5 \\
\hline 5. & Ladang/tegalan & 5 & 7 \\
\hline Jumlah & $\mathbf{1 5 0}$ & $\mathbf{1 0 0}$ \\
\hline
\end{tabular}

Berdasarkan Tabel 1, diatas menunjukan bahwa, penggunaan lahan di kampung lismaunggu sebagian besar adalah tanaman perkebunan kelapa sawit $75 \%$, perkarangan 10\%, ladang/tegalan 7\%, hutan/lahan/sungai 5\% dan fasilitas umum 3\%.

\section{Komoditas Tanaman Pangan}

Kampung lismaunggu memiliki komoditas tanaman pangan yang diusahakan oleh para petani seperti terlihat pada tabel 2 berikut:

Tabel 5. Komoditas tanaman pangan yang diusahakan

\begin{tabular}{clc}
\hline \hline No & Jenis Komoditi & Luas(Ha) \\
\hline \hline 1. & Jagung & 1,5 \\
2. & Ubi jalar & 2 \\
3. & Ubi kayu & 0,5 \\
4. & Kacang tanah & 0,5 \\
5. & Kedelai & 0,5 \\
\hline & Jumlah & $\mathbf{5 , 0}$ \\
\hline
\end{tabular}

Sumber: Data Sekunder 2019

Dari tebel 2 diatas menunjukan bahwa komoditi tanaman pangan yang banyak diusahakan adalah jagung 1,5 ha, ubi jalar 2 ha, ubi kayu 0,5 ha, kacang tanah 0,5 ha dan kedelai 0,5 ha. 
Prosiding Seminar Nasional Pembangunan dan Pendidikan Vokasi Pertanian

Politeknik Pembangunan Pertanian Manokwari, 14 November 2020

e ISSN : 2774-1982

\section{Keadaan Penduduk}

Kampung Desay mempunyai jumlah penduduk sebanyak 150 kepala keluarga (kk) dengan jumlah 383. Terdiri dari 185 jiwa pria (49\%) dan 198 jiwa wanita (51\%), seperti pada tabel 4 berikut ini:

\section{Penduduk Berdasarkan Pendidikan}

Klasifikasi penduduk berdasarkan tingkat pendidikan di Kampung Lismaunggu seperti pada tabel 5 dibawah ini:

Tabel 6. Klasifikaksi penduduk berdasarkan pendidikan

\begin{tabular}{llc}
\hline \hline No & Kelompok Pendidikan & Jumlah Jiwa \\
\hline 1. & BS/TS & 107 \\
2. & TK & 13 \\
3. & SD & 177 \\
4. & SLPT & 52 \\
5. & SLTA & 31 \\
\hline 6. & Diploma I/II/III & 3 \\
\hline \hline Jumlah & $\mathbf{3 8 3}$ \\
\hline Sumber Data: Dari aparat kampung Lismaunggu 2019
\end{tabular}

Dari data tabel 7 diatas, jumlah penduduk berdasarkan tingkat pendidikan di Kampung Lismaunggu sebanyak 383. Dari jumlah tersebut tingkat pendidikan yang paling tertinggi adalah Diploma I/II/III.

\section{Penduduk berdasarkan mata pencarian}

Keadaan Penduduk berdasarkan mata pencarian di Kampung Lismaunggu sebagai berikut:

Tabel 7. Berdasarkan Mata Pencarian

\begin{tabular}{llc}
\hline \hline No & Mata Pencarian & Jumlah \\
\hline 1. & PNS & 1 \\
2. & Pendeta/ Gembala Sidang & 5 \\
3. & Petani / Karyawan PTP & 144 \\
\hline & $\mathbf{1 . 1 . 1} \quad$ Jumlah & $\mathbf{1 5 0}$ \\
\hline
\end{tabular}

Sumber Data: Kampung Lismaunggu 2019 
Prosiding Seminar Nasional Pembangunan dan Pendidikan Vokasi Pertanian

Politeknik Pembangunan Pertanian Manokwari, 14 November 2020

e ISSN : 2774-1982

\section{Penduduk Berdasarkan Kelompok Umur}

Tabel 8. Jumlah penduduk kelompok umur Tahun 2019.

\begin{tabular}{lclccc}
\hline \multirow{2}{*}{ No } & \multirow{2}{*}{ Kelompok Umur (Tahun) } & \multicolumn{2}{c}{ Jumlah Jiwa } & \multirow{2}{*}{ Jumlah } \\
\cline { 3 - 4 } & & Laki-laki & Perempuan & \\
\hline 1. & 0 & -5 & 40 & 50 & 90 \\
2. & 6 & -15 & 46 & 55 & 101 \\
3. & $16-55$ & 61 & 58 & 119 \\
4. & $>55$ & 38 & 40 & 78 \\
\hline & $\mathbf{1 . 1 . 2}$ & Total & $\mathbf{1 8 5}$ & $\mathbf{1 9 8}$ & $\mathbf{3 8 3}$ \\
\hline
\end{tabular}

Sumber Data: Kampung Lismaunggu 2019

Jumlah penduduk menurut status keluarga di Kampung Lismaunggu adalah sebagai berikut: Jumlah penduduk yang memiliki status keluarga tani sebanyak $144 \mathrm{KK}$, dan jumlah penduduk bukan kepala keluarga tani sebanyak $6 \mathrm{KK}$, maka secara keseluruhan jumlah penduduk menurut status keluarga di Kampung Lismaunggu sebanyak 150 Kepala keluarga.

\section{Penduduk Berdasarkan Agama}

Tabel 9. Agama penduduk di Kampung Lismaunggu Tahun 2019

\begin{tabular}{|c|c|c|}
\hline No & Keragaman Agama & Jumlah \\
\hline 1. & Kristen Protestan & 227 \\
\hline 2. & Kristen Katolik & 85 \\
\hline 3. & Islam & 71 \\
\hline & Jumlah & 383 \\
\hline
\end{tabular}

Sumber Data: Kampung Lismaunggu 2019

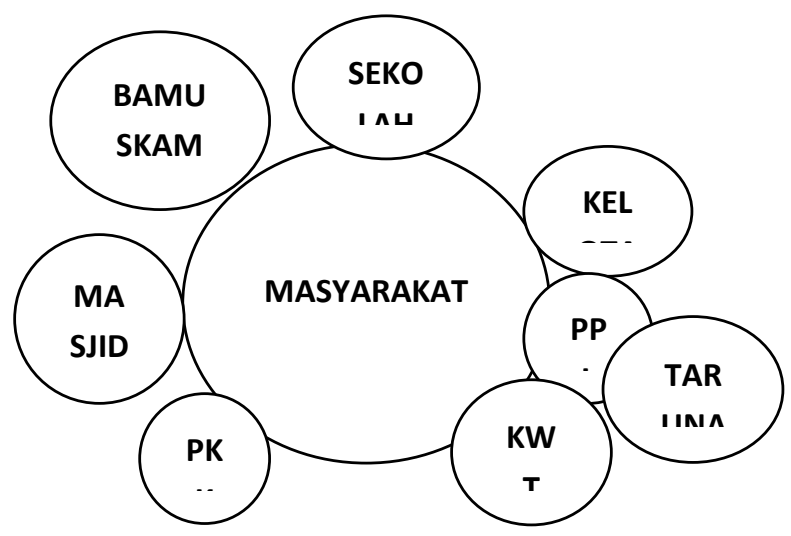

Gambar 1. Diagram Venn Hubungan Kelembagaan Dengan Masyarakat Lismaunggu 2019

Berdasarkan gambaran data diagram venn menunjukan hubungan kelembagaan yang ada di Kampung Lismaunggu, yang menunjukan bahwa kelembagaan yang memiliki jarak yang jauh dengan masyarakat adalah BAMUSKAM, Sekolah, Gereja dan PKK. 
Prosiding Seminar Nasional Pembangunan dan Pendidikan Vokasi Pertanian

Politeknik Pembangunan Pertanian Manokwari, 14 November 2020

e ISSN : 2774-1982

\section{Hasil Penelitian}

Berdasarkan hasil pengambilan data, maka diperoleh tabel hasil Evaluasi tingkat pengetahuan petani terhadap cara pembuatan dan pemanfaatan Pupuk Organik Cair (POC) dari Batang Pisang dikelompok tani Sougp Hatam 1 Kampung Lismaunggu, Distrik Prafi, Kabupaten Manokwari, Provinsi Papua Barat adalah sebagai berikut :

Tabel 10. Hasil Evaluasi

\begin{tabular}{|c|c|c|c|c|c|c|c|c|}
\hline \multirow{2}{*}{ No } & \multirow{2}{*}{ Indikator } & Ya & Tidak & \multirow{2}{*}{ JUMLAH } & \multirow{2}{*}{ SKOR } & \multirow{2}{*}{ Mean } & \multirow{2}{*}{$\begin{array}{l}\text { TCR } \\
(\%)\end{array}$} & \multirow{2}{*}{ KATEGORI } \\
\hline & & 5 & 1 & & & & & \\
\hline & $\begin{array}{l}\text { Alat Dan } \\
\text { Bahan POC }\end{array}$ & & & & & & & \\
\hline 1 & Alat & 15 & 0 & 15 & 75 & 5 & 100 & Sangat Baik \\
\hline 2 & Bahan & 15 & 0 & 15 & 75 & 5 & 100 & Sangat Baik \\
\hline 3 & Bahan & 15 & 0 & 15 & 75 & 5 & 100 & Sangat Baik \\
\hline \multirow[t]{2}{*}{4} & Bahan & 15 & 0 & 15 & 75 & 5 & 100 & Sangat Baik \\
\hline & $\begin{array}{l}\text { Langkah - } \\
\text { Langkah } \\
\text { Pembuatan } \\
\text { POC }\end{array}$ & & & & & & & \\
\hline 5 & $\begin{array}{l}\text { Pencampuran } \\
\text { Bahan }\end{array}$ & 15 & 0 & 15 & 75 & 5 & 100 & Sangat Baik \\
\hline 6 & $\begin{array}{l}\text { Pencampuran } \\
\text { Bahan }\end{array}$ & 15 & 0 & 15 & 75 & 5 & 100 & Sangat Baik \\
\hline 7 & $\begin{array}{l}\text { Pencampuran } \\
\text { Bahan }\end{array}$ & 15 & 0 & 15 & 75 & 5 & 100 & Sangat Baik \\
\hline 8 & $\begin{array}{l}\text { Pencampuran } \\
\text { Bahan }\end{array}$ & 15 & 0 & 15 & 75 & 5 & 100 & Sangat Baik \\
\hline \multirow[t]{2}{*}{9} & $\begin{array}{l}\text { Pencampuran } \\
\text { Bahan }\end{array}$ & 15 & 0 & 15 & 75 & 5 & 100 & Sangat Baik \\
\hline & $\begin{array}{l}\text { Karakteristik } \\
\text { Pembuatan } \\
\text { POC }\end{array}$ & & & & & & & \\
\hline 10 & $\begin{array}{l}\text { Karakteristik } \\
\text { Warna POC }\end{array}$ & 15 & 0 & 15 & 75 & 5 & 100 & Sangat Baik \\
\hline \multirow[t]{2}{*}{11} & $\begin{array}{l}\text { Karakteristik } \\
\text { Aroma POC }\end{array}$ & 15 & 0 & 15 & 75 & 5 & 100 & Sangat Baik \\
\hline & $\begin{array}{l}\text { Manfaat } \\
\text { POC }\end{array}$ & & & & & & & \\
\hline 12 & Manfaat POC & 15 & 0 & 15 & 75 & 5 & 100 & Sangat Baik \\
\hline 13 & Manfaat POC & 15 & 0 & 15 & 75 & 5 & 100 & Sangat Baik \\
\hline 14 & Manfaat POC & 15 & 0 & 15 & 75 & 5 & 100 & Sangat Baik \\
\hline
\end{tabular}

Sumber : Data Primer 
Prosiding Seminar Nasional Pembangunan dan Pendidikan Vokasi Pertanian

Politeknik Pembangunan Pertanian Manokwari, 14 November 2020

e ISSN : 2774-1982

Berdasarkan hasil pada tabel diatas dapat disimpulkan sejauh mana kesesuaian tingkat pengetahuan petani terhadap cara pembuatan dan pemanfaatan Pupuk Organik Cair (POC) dari Batang Pisang dikelompok tani Sougp Hatam 1 Kampung Lismaunggu, Distrik Prafi, Kabupaten Manokwari, Provinsi Papua Barat hasil soal 1 sampai 14. Maka tingkat pengetahuan petani terhadap cara pembuatan dan pemanfaatan Pupuk Organik Cair (POC) dari Batang Pisang dikelompok tani Sougp Hatam 1 Kampung Lismaunggu, Distrik Prafi, Kabupaten Manokwari, Provinsi Papua Barat termaksud kategori sangat baik.

\section{Pembahasan}

\section{Tingkat Pengetahuan Kelompok Tani Sougp Hatam 1 Terhadap Cara Pembuatan POC Dari Batang Pisang}

Distrik prafi adalah salah satu distrik di wilayah kabupaten manokwari yang berpenduduk masyarakat HATAM dan memiliki rata - rata petaninya adalah petani transmigrasi. Salah satunya kampung lismaunggu.

Berdasarkan hasil penelitian pada kelompok tani Sougp Hatam 1 tingkat pengetahuan petani terhadap cara pembuatan Pupuk Organik Cair (POC) dari Batang Pisang dengan menggunakan teknik pengumpulan data dan metode penelitian. Maka hasil analisis data yang peroleh peneliti dengan menggunakan rumus interval dikelompok tani Sougp Hatam 1 berdampak sangat baik pada kelompok tani Sougp Hatam 1.

\section{Tingkat Pengetahuan Kelompok Tani Sougp Hatam 1 Terhadap Pemanfaatan POC}

\section{Dari Batang Pisang}

Berdasarkan hasil penelitian pada kelompok tani Sougp Hatam 1 tingkat pengetahuan petani terhadap pemanfaatan Pupuk Organik Cair (POC) dari Batang Pisang dengan menggunakan teknik pengumpulan data dan metode penelitian. Maka hasil analisis data yang peroleh peneliti dengan menggunakan rumus interval dikelompok tani Sougp Hatam 1 berdampak sangat baik pada kelompok tani Sougp Hatam 1.

\section{KESIMPULAN DAN SARAN}

\section{KESIMPULAN}

Berdasarkan hasil penelitian yang telah dilakukan dapat disimpulkan sebagai berikut: adanya kesesuaian antara pelaksanaan dengan pedoman cara pembuatan Pupuk Organik Cair (POC) dari Batang Pisang dikelompok tani Sougp Hatam 1 Kampung Lismaunggu, Distrik Prafi, Kabupaten Manokwari, Provinsi Papua Barat sangat baik serta peningkatan pengetahuan tentang pemanfaatan Pupuk Organik Cair (POC) dari Batang 
Prosiding Seminar Nasional Pembangunan dan Pendidikan Vokasi Pertanian

Politeknik Pembangunan Pertanian Manokwari, 14 November 2020

e ISSN : 2774-1982

Pisang dikelompok tani Sougp Hatam 1 Kampung Lismaunggu, Distrik Prafi, Kabupaten Manokwari, Provinsi Papua Barat sangat baik.

\section{SARAN}

Berdasarkan kesimpulan yang diperoleh dari hasil penelitian minat generasi muda terhadap dunia pertanian di Kampung Desay, maka saran atau rekomendasi sebagai berikut. Penelitian ini dapat dilanjutkan dengan dengan melihat variabel-variabel lainnya yang dapat berpotensi menimbulkan kesesuaian dan pelaksanaan terhadap cara pembuatan POC dari batang pisang. Penelitian ini dapat dilanjutkan dengan dengan melihat indikator indikator lainnya yang dapat berpotensi menimbulkan pengetahuan pemanfaatan terhadap POC dari batang pisang.

\section{DAFTAR PUSTAKA}

Arikunto, S. (2007). Manajemen Penelitian. Jakarta: PT Rineka Cipta Diakses 19 Juni 2020 .

Budiyani, Ni Komang, Ni Nengah Soniasari, \& Ni Wayan Sri Sutari. (2016). Analisis Kualitas Larutan Mikroorganisme Lokal (MOL) Bonggol Pisang”. E-Jurnal Akroekoteknologi Tropika.Vol. 5, No. 1. Diakses 19 Juni 2020.

Charlita Herantoro, M. Mardhiansyah, \& Evi Sribudiani. (2015). APLIKASI KOMPOS BATANG PISANG TERHADAP PERTUMBUHAN SEMAI JABON (Anthocephalus cadambaMiq.) PADA MEDIUM GAMBUT. Jom Faperta Universitas Riau Vol. 2, No. 1, Februari 2015. Diakses 19 Juni 2020.

Erlangga, Jakarta.Fitria, Yulya, Bustami Ibrahim, \& Desniar. (2008). Pembuatan Pupuk Organik Cair dari Industri Perikanan Menggunakan Asam Asetat dan EM4(Effective Microorganisme 4). Jurnal Sumberdaya Perairan, Vol. 1. Diakses 19 Juni 2020.

Hanafiah. (2005). Dasar-dasar Ilmu Tanah. Jakarta: Raja Grafindo Persada. Hawley, Gessner, 1981, The Condesed. Diakses 19 Juni 2020.

Hadisuwito, S. (2012). Membuat Pupuk Organik Cair. Agromedia Pustaka. Jakarta. Diakses 19 Juni 2020.

Kartasapoetra, A.G., (1988). Teknologi Penyuluhan Pertanian. Bumi Aksara, Jakarta. Diakses 19 Juni 2020.

Lingga, P. (2007). Petunjuk Penggunaan Pupuk. Penebar Swadaya, Jakarta. Diakses 19 Juni 2020.

Luthfianto, Dodik, Edwi Mahajoeno, \& Sunarto. (2012). Pengaruh Macam Limbah Organik dan Pengenceran terhadap Produksi Biogas dari Bahan Biomassa Peternakan Ayam. Bioteknologi.Vol 9. No 1. Hal 18-29. Diakses 19 Juni 2020.

Mardikanto, T. (1999). Penyuluhan Pembangunan Pertanian, Universitas Sebelas Maret, Surakarta. Diakses 19 Juni 2020. 
Prosiding Seminar Nasional Pembangunan dan Pendidikan Vokasi Pertanian

Politeknik Pembangunan Pertanian Manokwari, 14 November 2020

e ISSN : 2774-1982

Marsono \& Sigit Paulus. (2001). Pupuk Akar Mc Cabe. W.L. Smith,J.C and Harriot P, 1993. ments/2011. Diakses 19 Juni 2020.

Nazir, M. (1999). Metode Penelitian. Ghalia Indonesia, Jakarta. Diakses 19 Juni 2020.

Padmowihardjo, S. (2000). Metode Penyuluhan Pertanian, Universitas Terbuka, Jakarta. Diakses 19 Juni 2020.

Parman, Sarjana. (2007). Pengaruh Pemberian POC Terhadap Pertumbuhan dan Produksi Kentang (Solanum Tuberosum L.). Buletin Anatomi dan Fisiologi. 15 (2): 21-31. Diakses 19 Juni 2020.

Pribadi, Charlita Herantoro, M. Mardhiansyah, \& Evi Sribudiani. (2015). APLIKASI KOMPOS BATANG PISANG TERHADAP PERTUMBUHAN SEMAI JABON (Anthocephalus cadambaMiq.) PADA MEDIUM GAMBUT. Jom Faperta Universitas Riau Vol. 2, No. 1. Diakses 19 Juni 2020.

Sugiyono. (2013). Metode Penelitian Kuantitatif Kualitatif dan R\&D. Bandung: Alfabeta. . di akses Diakses 19 Juni 2020.

Samsudin, U. (1987). Dasar-dasar Penyuluhan dan Modernisasi Pertanian,Bina Cipta, Bandung. Diakses 19 Juni 2020.

Santi, Shinta Soraya. (2010). Kajian Pemanfaatan Limbah Nilam untuk Pupuk Cair Organik dengan Proses Fermentasi. Jurnal Teknik Kimia, Vol. 4, No.2, April Swadaya, Jakarta. Diakses 19 Juni 2020.

Sukandar Wiraatmaja, dkk. Penyuluhan Pertanian. Jakarta: Departemen Pendidikan dan Kebudayaan. hlm. 143. Diakses 19 Juni 2020.

Sukandar Wiraatmaja, dkk. Penyuluhan Pertanian. Jakarta: Departemen Pendidikan dan Kebudayaan. hlm. 140. Diakses 19 Juni 2020.

Sukandar Wiraatmaja, dkk. Penyuluhan Pertanian. Jakarta: Departemen Pendidikan dan Kebudayaan. hlm. 142. Diakses 19 Juni 2020.

Sukandar Wiraatmaja, dkk. Penyuluhan Pertanian. Jakarta: Departemen Pendidikan dan Kebudayaan. hlm. 148. Diakses 19 Juni 2020.

Sutanto, R. (2002). Penerapan Pertanian Organik. Kanisius, Yogyakarta. Diakses 19 Juni 2020.

Suprihatin. (2011). Production Process of Liquid Fertilizer from Banana Trunk. Jurnal Teknik Kimia, 5 (2): 429-433. Diakses 19 Juni 2020.

Satuhu, S. \& Supriyadi, A. (1999). Pisang Budidaya, Pengolahan dan Prospek Pasar. Penebar Swadaya. Jakarta. Diakses 19 Juni 2020.

Saraiva, B., Pacheco, E.B.V., Visconte, L.L.Y., Bispo, E.P., Escócio, V.A., de Sousa, A.M.F., Soares, A.G., Junior, M.F., Motta, L.C.D.C., \& Brito, G.F.D.C. (2012). Potentials for Utilization of Post-Fiber Extraction Waste From Tropical Fruit Production in Brazil - the Example of Banana Pseudo-Stem. International Journal of Environment and Bioenergy. 4 (2) : 101 - 119. Diakses 19 Juni 2020. 
Prosiding Seminar Nasional Pembangunan dan Pendidikan Vokasi Pertanian

Politeknik Pembangunan Pertanian Manokwari, 14 November 2020

e ISSN : 2774-1982

Van den, A.W. \& Hawkins, A.S. (2001). Penyuluhan Pertanian, Kanisius, Yogyakarta. Diakses 19 Juni 2020.

W. van den Ban (1999). Penyuluhan Pertanian. Yogyakarta: Kanisius. hlm. 23, 24, 30. ISBN 978-979-672-342-3. Diakses 19 Juni 2020. 